\title{
Fear, Loathing, and the First Amendment: Optimistic Skepticism and the Theory of Free Expression
}

MARTIN H. REDISH*

TABLE OF CONTENTS

I. Introduction: The Siren CALl of COMmUNitARIAN Free SPEECH THEORY 691

II. John Rawls, American Democracy, AND the Value of MUTUAL Mistrust ....

III. The CONCEPT OF SKEPTICAL OPTIMISM: Mutual Mistrust, VIEWPOINT REGULATION, AND HUMAN FLOURISHING 698 IV. “I'M FROM THE GOVERNMENT AND I'M HERE TO HELP YOU”: DRAWING A SPEECH-CONDUCT DiCHOTOMY.................................. 700

V. ABSOLUtism AND the ADVERSARY FIRST AMENDMENT.................702

VI. CONCLUSION: THE NEED to RETHINK AMERICAN DEMOCRACY ... 703

\section{InTROduCtion: THE SiREN CALl OF COMMUNITARIAN FREE SPEECH THEORY}

The theory of communitarianism has always had a special appeal to Americans. It is more satisfying to focus on what holds us together than on what keeps us apart, or-even worse-what keeps us at odds. Thus, after 9/11, in a show of American solidarity, members of Congress from both parties gathered together on the steps of the Capitol and sang the Star Spangled Banner. ${ }^{1}$ Holidays like the Fourth of July and symbols such as the American flag and the Pledge of Allegiance are undoubtedly designed to make us all feel part of a unified whole, sharing a common purpose. There is, of course, nothing wrong with such symbolic forms of connection among Americans. However, it is when the assumed inter-connectivity is taken beyond the level of the symbolic and extended to core notions of political theory that we should become concerned. For it is far too easy to make the short leap from communitarian sharing of common purposes to societal condemnation of anyone who departs from some predetermined understanding of what those common purposes are. The result is, potentially at least, the suppression of differing views, which, ironically, would itself undermine what many consider

* Louis and Harriet Ancel Professor of Law and Public Policy, Northwestern University School of Law. The author thanks Ronald Krotoszynski and Andrew Koppelman for their valuable comments.

${ }^{1}$ Sunlen Miller \& John Parkinson, Congress Sings God Bless America, ABC NEWS (Sept. 11, 2012, 1:11 PM), http://abcnews.go.com/blogs/politics/2012/09/congress-singsgod-bless-america-on-9/11-anniversary/, archived at http://perma.cc/PMU7-KVAS. 
our core "public purpose" to be-namely, preservation of the right of the individual to dissent from widely shared values and understandings.

In the context of the theory of free expression, as Professor Krotoszynski's cogent essay demonstrates, ${ }^{2}$ communitarian based theories have played an enormously important role in shaping our foundational understanding of the purposes of our national commitment to free and open communication. Indeed, many of the leading free speech theorists of the twentieth and twenty-first centuries could, in one sense or another, be appropriately characterized as communitarian at their core. For example, as Professor Krotoszynski says, ${ }^{3}$ Cass Sunstein's free speech theory derives from a modern civic republican version of a communitarian pursuit of common public interests. ${ }^{4}$ Robert Post's participatory theory of free expression is, in its essence, also focused on the pursuit of common purposes. ${ }^{5}$ More recently, relative newcomer Zephyr Teachout has proposed a theory that seeks to actually hold unconstitutional even private individuals' attempts to influence governmental decision making for any reason other than pursuit of "the public interest."6 But the father of all communitarian theories of free expression is the one first propounded in the late 1940s by Alexander Meiklejohn. ${ }^{7}$ Meiklejohn located the right of free expression exclusively in the listener. ${ }^{8}$ It was not important, he wrote, that everyone have the opportunity to speak, only that everything worthwhile be said. ${ }^{9}$ The voters need such an open flow of information and opinion, he reasons, in order to perform their function as the true governors in a democratic society. ${ }^{10}$ In Meiklejohn's words, the "primary purpose of the First Amendment is ... that all citizens shall, so far as possible, understand the

2 Ronald J. Krotoszynski, Jr., Free Speech Paternalism and Free Speech Exceptionalism: Pervasive Distrust of Government and the Contemporary First Amendment, 76 OHIO ST. L.J. 659 (2015).

${ }^{3}$ Id. at 667 .

${ }^{4}$ See Cass R. Sunstein, Beyond the Republican Revival, 97 YALE L.J. 1539, 1576-78 (1988) [hereinafter Sunstein, Beyond]; see also CASS R. SunsteIn, DEMOCRACY AND THE Problem of Free SPEECH 19-23 (1993).

${ }^{5}$ See Robert Post, Meiklejohn's Mistake: Individual Autonomy and the Reform of Public Discourse, 64 U. Colo. L. ReV. 1109, 1115-23 (1993). But see MARTIN H. RedisH, THE AdVERSARY FIRST AMENDMENT: FreE EXPRESSION AND THE Foundations OF AMERICAN DEMOCRACY 31-32 (2013) ("Post has argued that 'the value of individual autonomy is inseparable from the ... aspiration for self-government.' He has, moreover, insisted that 'the ideal of autonomy is . . foundational for the democratic process.' In reality, however, Post's commitment to autonomy-both individual and collective-is limited at best." (footnotes omitted)).

${ }^{6}$ Zephyr Teachout, The Anti-Corruption Principle, 94 CORnELl L. REV. 341, 374 (2009). (1948).

${ }^{7}$ Alexander Meiklejohn, Free Speech and Its Relation to Self-Government

${ }^{8}$ See id. at 25.

${ }^{9}$ See id. (The First Amendment "does not require that... every citizen shall take part in public debate" nor that "everyone . . have [the] opportunity to do so.").

${ }^{10}$ See id. at 24-26. 
issues which bear upon our common life." 11 He disdained any focus on the private right to speak, ${ }^{12}$ and categorically rejected extending First Amendment protection to private lobbying efforts or commercial radio stations. ${ }^{13}$ Indeed, Meiklejohn drew a sharp distinction between "public" speech, which was to be fully protected by the First Amendment, and "private" speech, which was to be excluded from the scope of First Amendment protection, instead being relegated to the far more limited protection of the Fifth Amendment's Due Process Clause. ${ }^{14}$

To be sure, the concept of a unified, widely understood "public interest" which we as members of society are all pursuing presents an attractive vision for Americans. The problems with the communitarian vision of free expression, however, are many, on at least three important levels. First, it is all too easy to identify the public interest with one's own ideological perspective; after all, if one believes that one's own beliefs represent moral and political truth, then expression advocating a contrary position must logically be against the public interest. Thus, an exclusive constitutional focus on speech deemed to pursue the public interest is potentially the first step on the road to imposition of viewpoint-based regulation. Indeed, investing any branch of government, including the judiciary, with power to ascertain whether, in the individual case, speech does or does not pursue the public interest provides a ready subterfuge for the imposition of viewpoint suppression. Second, the very decision to protect only speech designed to foster the public interest is in and of itself a form of viewpoint suppression. One widely accepted politicaleconomic ideology, associated with free market economics, posits that the "public interest" is nothing more than the sum total of each individual's private interests. ${ }^{15}$ Therefore the very requirement that speech be designed to promote the public interest itself represents an implicit rejection of this economic viewpoint. Third, a forced focus on nothing but pursuit of the public interest undermines the individualism that is appropriately understood to underlie the liberal tradition. Individuals are permitted to pursue and protect their own personal values and interests, regardless of whether some external, objective arbiter would find that interest to overlap with that of the public in general.

It is my view that any model of free speech theory grounded purely in notions of some form of communitarian pursuit of the public interest ignores a real understanding of what America's democratic society is all about. Even casual examinations of American political history demonstrates that it has been pluralism and diversity, rather than some sort of homogeneous consensus on virtually all matters, that inherently characterizes America's form of

${ }^{11} I d$. at 88-89 (emphasis added).

12 See supra text accompanying notes 8-9.

${ }^{13}$ MeIKLEJOHN, supra note 7, at 39.

${ }^{14}$ Id. at 39-40; see U.S. CONST. amend. V.

15 JANE J. MANSBRIDGE, BEYOND ADVERSARY DEMOCRACY 17 (1980). 
democracy. In this Essay, I will argue the following: (1) America's political and constitutional traditions have, for the most part, focused upon managing conflicts among competing groups of individuals in a manner designed to preserve the essential elements of democracy; (2) the best way to visualize such management is by an analogy to John Rawls's state of nature behind the veil of ignorance; (3) the guarantee of free expression is appropriately viewed as one form - and arguably the most important form - of political conflict management; (4) the skepticism inherent in this conflict management version of American political theory should be seen as a means of preserving and promoting human flourishing; and (5) the mistrust of government's power to censor individual expression does not automatically extend to an equal mistrust of governmental power to regulate private conduct.

The next section of this Essay explores the history and theory of the conflict management model of American democratic theory, finding it to inhere in the structure of the nation's constitutional and political structure. ${ }^{16}$ The section also visualizes the American system of constitutional management of conflict by means of an analogy to the Rawlsian framework. ${ }^{17}$ The section that follows emphasizes the optimistic element of the skepticism inherent in our form of democracy, discussing the important intersection between skepticism and mistrust on the one hand and human flourishing on the other. ${ }^{18}$ The final section will draw a distinction between mistrust of governmental suppression of expression on the one hand and governmental regulation of conduct on the other hand. ${ }^{19}$

\section{JOHN RAWLS, AMERICAN DEMOCRACY, AND THE VALUE OF MUTUAL MistRUST}

The struggle for American political theory has been to avoid the dark pathologies that potentially plague conflicts that inhere in a pluralistic society. In short, the goal has been to manage the conflict inherent in social and political diversity in a manner that prevents degeneration into tyranny. This can only be achieved by starting from a principle of universal mistrust, or, to put it another way, "in God we trust: all others pay cash." 20 But naked mistrust, standing alone, could easily lead to widespread "prisoners' dilemma" problems $^{21}$ and as a result degeneration into a political state of nature where,

${ }^{16}$ See infra Part II.

${ }^{17}$ See infra Part II.

18 See infra Part III.

${ }^{19}$ See infra Part IV.

${ }^{20}$ I take the phrase from the well-known book by humorist Jean Shepherd. JEAN SHEPHERD, IN God We TRUst, All Others PAy CASH (1966).

${ }^{21}$ For a detailed description of the so-called "prisoners' dilemma," see REDISH, supra note 5 , at $12-13$. 
as Thomas Hobbes warned, life is nasty, brutish and short. ${ }^{22}$ Instead, the mutual mistrust that rightfully pervades the relationships among individuals and groups must be channeled in ways that place a democratic floor below the adversary battle among different interest groups and ideologies. ${ }^{23}$ Our constitutional structure in general and the First Amendment in particular represent that floor. ${ }^{24}$

Perhaps the best way to articulate the rationale behind this "adversary" version of American democracy is to draw on an analogy to the famed political philosopher, John Rawls. One need not accept all of Rawls's controversial moral conclusions to recognize the intuitive value of his imaginary constructs as to the beginnings of civilized society. Rawls first imagines individuals in a pre-societal state of nature, what he refers to as "the original position." 25 In this original position, he presumes that "the parties ... are equal. That is, all have the same rights in the procedure for choosing principles [that will govern society once it is formed]; each can make proposals, submit reasons for their acceptance, and so on."26

Most importantly, for my purposes, is that Rawls assumes that the parties in this original position "are situated behind a veil of ignorance. They do not know how the various alternatives will affect their own particular case and they are obliged to evaluate principles solely on the basis of general considerations." 27 Thus, for those in the original position:

$[\mathrm{N}] \mathrm{o}$ one knows his place in society, his class position or social status; nor does he know his fortune in the distribution of natural assets and abilities, his intelligence and strength, and the like. Nor, again, does anyone know his conception of the good, the particulars of his rational plan of life, or even the special features of his psychology such as his aversion to risk or liability to optimism or pessimism. ${ }^{28}$

Moreover, Rawls assumes:

that the parties do not know the particular circumstances of their own society. That is, they do not know its economic or political situation, or the level of civilization and culture it has been able to achieve. The persons in the original position have no information as to which generation they belong.... They

${ }^{22}$ See Thomas HobBes, Leviathan 77 (A.P. Martinich ed., Broadview Press Ltd. 2002) (1651).

${ }^{23}$ See REDISH, supra note 5, at 136-41.

${ }^{24}$ See U.S. CONST. arts. I, II \& III, amend. I.

25 John RAWLS, A THEORY OF Justice 17 (1971) ("[T]he original position is the appropriate initial status quo which insures that the fundamental agreements reached in it are fair .... [W] have to ascertain which principles it would be rational to adopt given the contractual situation.").

${ }^{26} \mathrm{Id}$. at 19 .

27 Id. at 136-37.

${ }^{28}$ Id. at 137. 
must choose principles the consequences of which they are prepared to live with whatever generation they turn out to belong to. ${ }^{29}$

However, in this mythical pre society Rawls does assume that individuals "know the general facts about human society. They understand political affairs and the principles of economic theory; they know the basis of social organization and the laws of human psychology."30

On the basis of this highly abstract construct, Rawls infers choices of risk averseness; those in the original position, for example, will be presumed not to decree that whites may suppress blacks or that men may suppress women, because they don't know themselves, behind this veil of ignorance, whether they will be white or black or male or female. As another famous political philosopher, Clint Eastwood's character Dirty Harry, once put it, do you "feel lucky? Well, do ya, punk?"31 Both Rawls and Harry reflect a concern for the risk averseness that should rationally flow from a lack of key information as to one's own power or status.

One might dispute Rawls's rather blanket assumption of universal moral risk averseness as a theoretical matter, but there is little doubt that something akin to that underlies the commitments made by our nation in ratification of the First Amendment to the Constitution. Arguably, this is especially true of the commitment to religious freedom. By its nature-at least in most cases of which we have been made aware-commitment to a particular religion inherently carries with it a form of epistemological arrogance, or a belief in some higher, indisputable truth. Why, then, should one who knows what is true tolerate blasphemers - those who pray to false or even evil gods? The most logical answer is that at the outset, one can never be certain that his or her religion will be in a position actually to suppress other religions. Indeed, for all they know (standing behind the Rawlsian veil of ignorance), other religions will be in a far better position to suppress the decider's religion than the other way around. In a dark game theory sort of way, then, the constitutional commitment to religious freedom made by men who firmly believed in the universal truth and moral superiority of their own religion is nothing more than Dirty Harry saying, "feel lucky.... punk?"32 Much the same could be said for the nation's commitment to freedom of expression: one may privately be totally sure of the correctness or even truth of one's own position, but one operating behind the veil of ignorance cannot be certain that

${ }^{29} I d$.

${ }^{30} \mathrm{Id}$.

31 Dirty Harry (1971) Quotes, IMDB, http://www.imdb.com/title/tt066999/quotes (last visited Feb. 5, 2015), archived at http://perma.cc/DC29-659H.

${ }^{32} \mathrm{Id}$. One might respond that unlike those in the original position, the men who framed and ratified the First Amendment were not operating behind a veil of ignorance, but to the contrary, actually could be certain that their views were dominant. But those responsible for our Constitution were well aware of world history, where those in power were often replaced by others holding very different viewpoints. It is at this point that the risk averseness inherent in operating behind the veil of ignorance comes into play. 
in the future she will be in a position to suppress the expression of false viewpoints. Indeed the opposite may well turn out to be the case.

The First Amendment, then, is appropriately seen as a device designed (1) to recognize the inherent and pervasive potential for conflict among competing interests and value systems, and (2) to impose a type of "Marquess of Queensberry" set of procedural limitations on the operation of that conflict. ${ }^{33}$ To be sure, in an adversary democracy there will be winners and losers. But the understanding of the First Amendment is that the winners may not silence or punish the losers, once again because at the point the initial agreement among all is made, all operate behind the veil of ignorance and therefore do not know whether they will turn out to be winners or losers once society begins. Moreover, even if they are winners the first time, much as the Federalists found in in the election of 1800 , they may turn out to be big losers the next time.

The pervasiveness of the adversary model of democracy in American society is far more than merely the result of a theoretical construct. One need only look to the very beginning of our constitutional tradition to see the dynamic of interest group conflict at work in the very framing of the Constitution. ${ }^{34}$ Madison's famed Federalist No. 10 clearly reflects his awareness of the inevitability of faction within our society. ${ }^{35}$ It also reflects his effort to control this pathology, not through widespread suppression or some unrealistic, quixotic demand that everyone eschew personal interest to pursue some vague notion of the "public interest," but rather through resort to prophylactic methods of governmental structure designed to dilute the potential strength of any one faction. ${ }^{36}$ Indeed, the entire structure of the American Constitution, with its intricate system of separation of powers and checks and balances, ${ }^{37}$ appears openly premised on a premise of mutual mistrust. Moreover, one need not possess a $\mathrm{PhD}$ in either political science or history to know that interest group politics-like it or not-have long dominated American society. ${ }^{38}$ To pretend American society is something it is not now and never has been by imagining a tightly knit community working towards widely accepted goals is to do a disservice to what our nation's true political genius has been. And that is an ability to manage the inevitable

\footnotetext{
33 Marquess of Queensberry Rules, ENCYCLOPÆDIA BRITANNICA, http://www.britannica.com/EBchecked/topic/366079/Marquess-of-Queensberry-rules (last visited Mar. 2, 2015), archived at http://perma.cc/GG3U-456W.

${ }^{34}$ For a detailed historical discussion of the pervasiveness of interest groups in American society, see REDISH, supra note 5, at 136-41.

35 See The Federalist No. 10, at 71-77 (James Madison) (Clinton Rossiter ed., 1961).

36 See id.

${ }^{37}$ See, e.g., U.S. CONST. arts. I, II \& III.

38 See REDISH, supra note 5, at 136-41 (describing historical pervasiveness and importance of interest groups in American society).
} 
conflict among competing interests and values in a manner designed to preserve core notions of democratic practice and to avoid the onset of tyranny.

\section{The CONCEPT OF SKEPTICAl OPTIMISM: Mutual Mistrust, VIEWPOINT REGULATION, AND HUMAN FLOURISHING}

As dark as this view of human nature may appear to be, it also manifests an important element of optimism about the human condition that should not be ignored. First of all, those who decry the slavish pursuit of one's own personal interests ignore the fact that on many occasions they themselves value just such behavior, albeit viewed through a very different ideological lens. When welfare recipients picket for an increase in their benefits, they are using expression as a means of pursuing their own personal interests, regardless of whether an increase in benefits would be beneficial to society as a whole. When African Americans protest violations of their civil rights, they, too, are employing expression as a means of advancing their own personal interests. To be sure, many of us may well give moral approval to such personal pursuits, but that fact makes them no less the pursuit of individual interest. It is likely, then, that many who decry narrow pursuit of one's own interests are in reality condemning only those personal interests which they find morally offensive or with which they disagree. But it is at this point that the Rawlsian veil of ignorance must come into play, dictating that we cannot set up the rules of free expression selectively, on the basis of our own particular moral value system. ${ }^{39}$ For once such a principle is established, then those who hold the opposite viewpoint may just as rationally claim that when they take power they, too, may properly suppress expression of "offensive" viewpoints. The result is, once again, the very Hobbesian war of all against all that our entire system was designed to avoid in the first place. Feel lucky, punk?

It is this reasoning that has properly led the Supreme Court to invoke the First Amendment to categorically prohibit government from suppressing viewpoints with which government disagrees or deems offensive. ${ }^{40}$ There logically can be no exceptions, because once the Court makes an exception for one particular viewpoint that it or the political branches of government deem especially offensive, it has left the door open to any group who takes power to selectively suppress the views that it happens to deem offensive. ${ }^{41}$

It is for this reason that I cannot accept the assertion, discussed in Professor Krotoszynski's essay, ${ }^{42}$ that other nations can be said to maintain an

\footnotetext{
${ }^{39}$ RAWLS, supra note 25 , at 36-37.

${ }^{40}$ See, e.g., Gertz v. Robert Welch, Inc., 418 U.S. 323, 339 (1974) ("Under the First Amendment there is no such thing as a false idea.").

${ }^{41}$ I should note that a commitment to a total ban on viewpoint regulation does not necessarily imply a commitment to absolutism in First Amendment application. See infra Part V.

42 See Krotoszynski, Jr., supra note 2.
} 
effective system of free expression despite their categorical exclusion of certain views widely deemed offensive. To be sure, I am not suggesting that democracy is an all-or-nothing process; this fact does not necessarily render these societies the moral equivalent of tyrannical rule. However, in recognizing the authority of those in power to exempt from constitutional protection certain substantive views deemed offensive, these societies have left open the logical possibility that others who take power will be equally able to suppress viewpoints which they deem offensive. That does not represent a true commitment to the principles of democratic free expression, as dictated by the risk averseness and formal epistemological humility that appropriately grow out of an assumption of the veil of ignorance.

While acceptance of pluralism does have the potential to degenerate into power struggles and conflict, it also facilitates human flourishing far more than an exclusively communitarian perspective does. The liberal tradition has long been associated with a commitment to the notion of human growth and development. ${ }^{43}$ The paradox of our system, then, is that human flourishing can take place only when the darker aspects of human nature are recognized and checked. ${ }^{44}$ In this manner, the skepticism inherent in the notion of mutual mistrust effectively serves as a type of body guard for the more positive aspects of human nature. ${ }^{45}$

This is not to say that individuals should be deemed to exist in a vacuum, untied to each other in any meaningful way. It would indeed be absurd to suggest that we function as totally free individuals, divorced from civilized society. But it surely does not follow that recognition of the individual as an integral unit worthy of respect and capable of growth and development plays no proper role in modern liberal political theory. Most forms of communitarianism effectively push individualism to the background, dangerously risking the equation of pursuit of individual interest with pathological selfishness worthy of societal condemnation. Even more dangerous is the potential for appeals to communitarian values to be manipulatively employed by individuals or groups as nothing more than a disguised means to suppress unpopular views. This is true of both the political right, as shown all too clearly by the McCarthy era, and by the political left, as demonstrated by the modern left wing version of civic republicanism's attempt to exclude from the scope of the First Amendment speech deemed to promote values deemed morally offensive. ${ }^{46}$ Recognition of the inevitable battle among competing ideologies and interest groups for control, which characterizes the conflict management system of adversary democracy that is grounded in notions of mutual mistrust, enables us to see these appeals to vague notions of

\footnotetext{
${ }^{43}$ See John StUART Mill, On LiberTy 81 (1859).

${ }^{44}$ See id. at 81-82.

${ }^{45} \mathrm{See}$ id. at $82-83$.

${ }^{46}$ See Sunstein, Beyond, supra note 4, at 1577-78; Teachout, supra note 6, at 383-87.
} 
communitarian values for what they are. This recognition in turn enables us to prevent them from achieving their goals of selective suppression.

\section{IV. 'I'M FROM THE GOVERNMENT AND I'M HERE TO HELP YOU”: DRAWING A SPEECH-CONDUCT DiCHOTOMY}

While Professor Krotoszynski's excellent essay for the most part perceptively describes and explains my theory of the adversary First Amendment, ${ }^{47}$ I do have one important bone to pick with him. He seems to assume that my objection to governmental suppression of truthful advertising of prescription drugs somehow also includes a constitutional objection to the entire system of FDA approval for prescription drugs. ${ }^{48}$ It is not uncommon for observers to collapse my commitment to free and open discussion and communication into a form of substantive libertarianism that I have never advocated. ${ }^{49}$ The mere fact that I believe in a strong constitutional commitment to free expression does not necessarily lead me to embrace all forms of libertarianism, such as a belief in freedom for gun ownership or the right not to wear a motorcycle helmet. I see the two situations as fundamentally different as a matter of liberal political theory. The form of libertarianism to which I believe liberal political theory (and our Constitution) commit us is far narrower than a generic principle of substantive libertarianism. What is deserving of near total protection is what can appropriately be called "meta-libertarianism"-in other words, libertarianism about participation in the process of exercising liberty. For example, the making of appeals to others to seek to influence government to act in a particular manner is a form of meta-libertarianism, because it is the exercise of liberty to participate in the process of democracy.

Related to this concept is the fundamental distinction between speech and conduct. I have heard all of the arguments as to why speech and conduct must be treated as fungible for purposes of constitutional protection. ${ }^{50}$ But while I concede that on occasion the dangers of speech may be as great as those of conduct and correspondingly conduct may develop the intellectual and moral capacities of the individual as much or more than expression, one must recall that when the Framers drafted and ratified the First Amendment they were forced to make broad, categorical ex ante judgments. And the simple reality is that, for the most part, expression is less acutely harmful either to other individuals or to society, and, for the most part, conduct will provide less

\footnotetext{
47 See generally Krotoszynski, Jr., supra note 2, at 665-73 (discussing REDISH, supra note 5).

48 See Krotoszynski, Jr., supra note 2, at 672-73.

${ }^{49} \mathrm{I}$ am reminded of the time, at a conference at Berkeley Law School in 2007, when Professor John Harrison suggested that I need to get in touch with my "inner Epstein," referring, of course, to famed libertarian scholar Richard Epstein.

50 See, e.g., Frederick Schauer, Must Speech Be Special?, 78 Nw. U. L. REV. 1284, 1292-1300 (1983).
} 
direct benefit to the individual's intellectual development than expression. I also recognize that on occasion it will be difficult to separate speech from conduct on a conceptual level. ${ }^{51}$ But the same could be said for virtually all legal questions, and the number of occasions on which such a problem will arise is likely to be relatively small. Expression and three dimensional understanding of language are, for the most part, what distinguish humans from the rest of the animal kingdom. It is how we reason, communicate, and make decisions. It is therefore quite reasonable for the Framers to have decided to extend preeminent protection to expression, rather than to conduct, which is relegated to the far lower level of constitutional protection provided by the Fifth Amendment's Due Process Clause. ${ }^{52}$

When it comes to mistrust of governmental action, drawing a speechconduct regulatory distinction is equally appropriate. There are few governmental actions - short of summary arrests without judicial review or discrimination based on considerations of race or religion-more invidious to a viable democracy than governmentally imposed selective suppression of viewpoints deemed by those in power to be offensive or immoral. As to governmental regulations of conduct outside of the two exceptions mentioned, however, the populace has already been protected by the intricate system of process-based trip wires, speed bumps, and alarms inserted into the Constitution as a means of ensuring against precipitous or faction-based governmental action. While admittedly this is only true of the federal government, restrictions on states imposed by the Fourteenth Amendment have, for the most part, effectively limited state governmental abuses. As long as proposed governmental regulations of conduct comply with all structural constitutional limitations, are subject to full, free, and open debate, and remain so following their adoption, the threat of tyranny is not nearly as great as when expression has been selectively suppressed. When government censors one side of a public debate, the democratic process is fatally aborted. Thus, I have no problem, at least in the abstract, with governmental regulation of the production and sale of prescription drugs as a means of protecting public safety. However, when government allows sale of a drug but restricts truthful advertising for that drug, all of the democratic pathologies caused by censorship arise. For in such circumstances, government achieves its goal of regulation through the back door, thereby confusing or deceiving the public into believing that sale of the product is actually unregulated. Suppression of

${ }^{51}$ Compare Texas v. Johnson, 491 U.S. 397, 414-17 (1989) (holding that state's prohibition on desecration of the American flag violates First Amendment because regulation is aimed at substance of desecrater's message), with United States v. O'Brien, 391 U.S. 367, 376 (1968) (holding that burning draft card is not protected expression because government is regulating the act, rather than the message).

52 U.S. CONST. amend. V; see, e.g., Ferguson v. Skrupa, 372 U.S. 726, 730-31 (1963) (describing the low level of Due Process protection for economic behavior). 
speech advocating lawful conduct, then, enables government to engage in a form of stealth regulation of behavior. ${ }^{53}$

I should emphasize that by focusing on selective governmental suppression of one side of a public debate, I in no way intend to slight the value of more private forms of communication. Nor do I let anything turn on the motivation of the speaker who seeks to contribute to public debate. Promotion of self-interest, as we have already seen, is perfectly legitimate in an adversary democratic society. Moreover, given that the ultimate goal of the adversary model is to serve as a type of body guard to help protect and facilitate achievement of the goal of individual growth and flourishing, recognizing the right of each individual to communicate with others who are willing to listen flows logically from recognition of the adversary model in the first place.

\section{ABSOLUTISM AND THE AdVERSARY FIRST AMENDMENT}

Articulating the theoretical rationale underlying our nation's commitment to free expression on the one hand and determining the extent to which expression may be appropriately limited by government on the other hand present very different challenges. To be sure, my articulation of a managed adversary pluralism model grounded in precepts of mutual mistrust, while no doubt controversial, nevertheless tells us a great deal about which types of expression are deserving of protection. The model includes within the First Amendment's scope all forms of profit-motivated speech, an expressive category often excluded or given significantly reduced protection in the scholarly arena in general and in most communitarian-based expressive models. ${ }^{54}$ My model logically casts a particularly mistrustful eye to expressive restrictions grounded in either governmental notions of paternalism or viewpoint selectivity, since both are inconsistent with the premise of individual integrity inherent in the initial commitment to liberal democracy.

But contrary to Professor Krotoszynski's apparent assumption, ${ }^{55}$ outside of the two areas just mentioned my model is in no sense logically committed to a notion of expressive absolutism, any more than any other model of free expression is. For the most part, why we protect expression and how much expression we protect are distinct questions. It is true that my model logically does categorically exclude the two forms of expressive regulation already mentioned, but when government restricts unlawful advocacy or speech giving

\footnotetext{
53 Issues related to governmental suppression of advocacy of unlawful conduct give rise to more complicated questions that are beyond the scope of this Essay. For my views on that subject, see MARTIN H. ReDish, THE LOGIC OF PERSECUTION: FreE EXPRESSION AND THE MCCARTHY ERA 63-131 (2005); MARTIN H. REDISH, FREEDOM OF EXPRESSION: A CRITICAL ANALYSIS 173-211 (1984).

${ }^{54}$ See, e.g., MeIKLEJohn, supra note 7; TAMARA R. PIETY, BRANDishing THE FiRST AMENDMENT: COMMERCIAL EXPRESSION IN AMERICA 1-14 (2012).

55 See Krotoszynski, Jr., supra note 2, at 666-73.
} 
rise to imminent threats to public safety, or restricts the time, place, or manner of expression in reasonable ways, commitment to the adversary pluralism model says nothing - one way or the other - about the legitimacy of case-bycase exceptions to otherwise absolute protection. My prior writing has made clear, however, that even though I do not consider myself a First Amendment absolutist, I do believe that speech may be regulated only under the most compelling circumstances, and that speech advocating lawful activity can virtually never be suppressed. ${ }^{56}$

\section{CONCLUSION: THE NEED TO RETHINK AMERICAN DEMOCRACY}

The key fallacy of the communitarian models of free expression is not only normative; it is empirical as well. The simple fact is that, other than in the purely rhetorical sense, our nation has never operated on a one dimensional pursuit of the common good. Like it or not, interest groups have played an enormously important role in the growth and development of the United States. ${ }^{57}$ The notion that we should view the First Amendment right of free expression as some outgrowth of a democratic commitment to collaborative efforts to determine a common good is therefore either quixotically naïve or downright manipulative.

It is certainly true that our system of free expression is not for the faint of heart. Speech is often manipulative, underhanded, or downright nasty. But there is no other way to assure the continued effective operation of the democratic system and promotion of individual growth and development. As Madison wrote in Federalist No. 10 in regard to the idea of the suppression of factions, the cure here would be far worse than the disease. ${ }^{58}$

${ }^{56}$ See sources cited supra note 53 .

${ }^{57}$ See REDISH, supra note 5, at 136-41.

${ }^{58}$ The FederAlist No. 10, supra note 35, at 73 (James Madison). 
